13. Ryzhkov, A. (2017), Ukraine in Mexican mass media: April of 2017, Global Ukraine News, available at: http://global-ukrainenews.org/2017/05/08/ukrayina-v-meksykanskyh-zmi-kviten-2017-roku/ (ukr).

14. Ryzhkov, A. (2017), How Ukrainians extinguished information fire: an echo of hybrid war in distant Mexico?, Global Ukraine News, available at: http://global-ukraine-news.org/2017/05/24/yak-ukrayintsi-gurtom-informatsijnu-pozhezhu-gasyly-vidlunnyagibrydnoyi-vijny-v-dalekij-meksytsi/ (ukr).

15. Ryzhkov A., Lopez Rocha, N. (2017), Ukraine's cultural diplomacy in Mexico: Actors, projects and the image of Ukraine in the media, in Smagliy K. (ed.), Agora, vol. 18 "Cultural and public diplomacy of Ukraine, "Kyiv-Mohyla Academy" publishing, Kyiv, pp. 68-72 (ukr).

16. Ryzhkov A. (2017), Ukraine mirrored in Mexican press: May of 2017, Global Ukraine News, available at: http://global-ukrainenews .org/2017/06/08/ukrayina-v-dzerkali-meksykanskoyi-presy-traven-2017-roku/ (ukr).

17. Ryzhkov A. (2017), The image of Ukraine in Mexican press: June 2017, Global Ukraine News, available at: http://global-ukrainenews.org/2017/07/02/obraz-ukrayiny-v-meksykanskij-presi-cherven-2017-roku/ (ukr).

18. OKO (2017), Annual monitoring report: Ukraine in on-line media of the world in 2016, OKO, Kyiv, available at: http:// www.imagency.org.ua/wp-content/uploads/2017/03/Annual_report_print1.pdf (ukr).

19. The President of Ukraine (2017), Decree of the President of Ukraine № 47/2017 "On the decision of the National Security and Defense Council of Ukraine dated December 29, 2016 "On the doctrine of information security of Ukraine", available at: http:// www.president.gov.ua/documents/472017-21374 (ukr).

() Рижков Андрій, Лопес Роча Наєлі

Надійшла до редакції 09.06.2017

\title{
САННІКОВ СЕРГІЙ,
}

кандидат філософських наук, доктор богослов'я, стариий науковий співробітник,

Центр вивчення релігій Національного педагогічного університету ім. М. П. Драгоманова

\section{SOLA РЕФОРМАЦІї. БОГОСЛОВСЬКІ ПРИНЦИПИ ГЕТЕРОГЕННОГО ПРОТЕСТАНТИЗМУ}

\begin{abstract}
Стаття розкриває релігійно-богословські підстави, що дали початок реформаційному процесу, за допомогою популярних сьогодні індикаторів, відомих як 5 Sola Pеформації. Продемонстровано основні богословські принципи самоідентифікації протестантизму порівняно 3 іншими релігійними групами й показано, що герменевтика цих принципів розділяє протестантизм на багато течій, створюючи гетерогенність цього релігійного руху. Виконано порівняльний опис кожної 3 п'яти ознак богословської системи в розумінні магістерської та радикальної Реформації, подано історію появи 5 Sola i їхнє богословське значення. Найбільшу увагу приділено базовому формальному принципу всього протестантського руху - Sola Scriptura. Виявлено виклики, яких зазнає цей принцип у постмодерністському суспільстві, продемонстровано, що він означає і чого не означає в сучасному євангельському русі. Розкрито значення Sola gratia як системотвірного пункту богословської системи лютеранства. Виявлено різне розуміння віри і тлумачення принципу Sola fide в магістерській та радикальній формах протестантизму. Демонструються особливості застосування принципів Solus Christus i Soli Deo gloria в східній і західній християнських традиціях.
\end{abstract}

Ключові слова: Sola Scriptura ("тільки одним Писанням"); Sola gratia ("тільки однією благодаттю"); Sola fide ("тільки однією вірою"); Solus Christus ("тільки Христос"); Soli Deo gloria ("тільки Богу слава"); магістерська Рефрормація; радикальна Реформація; Лютер; східне християнство; західне християнство.

Постановка проблеми. Одним зі складних питань, які часто виникають під час святкування ювілею Реформації, є проблема історичної неминучості Реформації. Вона має багато прихильників, але й чимало противників. А й справді, чи була Реформація неминучою, чи ж вона сталася завдяки унікальному і єдино можливому збігу обставин? Інакше кажучи, чи відбулася б Реформація XVI століття, якби не було сутички Лютера і Теце- ля? Чи могла Західна Європа піти іншим шляхом розвитку? Чи можна було б обійтися без Тридцятирічної війни й без протестантської етики капіталізму? Звичайно, ми ставимо ці питання не для того, щоб повернути історію назад, а щоб осмислити шляхи розвитку сучасної цивілізації i, спираючись на попередній досвід, запропонувати оптимальні кроки в майбутнє.

А. МакГрат, провідний спеціаліст із вивчення Рефрор- 
мації, у своїй книзі "Небезпечна ідея в християнстві" один із розділів назвав "Гетерогенність раннього протестантизму". На історичному матеріалі він продемонстрував, що спочатку Реформація існувала як серія незалежних рухів із різними підходами й богословськими інтерпретаціями. І лише згодом, як стверджує А. МакГрат, "завдяки складній взаємодії людей, завдяки листуванню і публікації, характерних для того періоду, ці, спочатку самостійні рухи, змогли досягти хоча б часткового ступеня вирівнювання" [27, с. 62]. Багато дослідників доводить, що Реформація виникла в різних частинах Європи майже спонтанно й обумовлювалася низкою політичних, соціальних, економічних причин i, звичайно, релігійних і богословських чинників. Н. Бевзюк пише: "Як не випадково і не раптово церква набула форми ієрархії і римського папства, так само не випадково і не раптово настала Реформація. Вона вийшла із самої церкви, в якій визріла поступово" [1, с. 13]. Ренесанс і загальний стан релігійного суспільства підготували Реформацію, і перетворення повинні були початися саме з духовної і світоглядної сфери, яка тоді мала суто релігійну форму. Тому Реформація в широкому розумінні неминуче мала настати, але те, що вона відбулася в XVI ст. як набір різних релігійно-політичних рухів, які цілком змінили релігійну карту Західної Європи, обумовлено, на наш погляд, низкою суб'єктивних факторів. Якщо погодитися, що Реформація як богословсько-релігійне та суспільно-політичне явище була неминучою, то які духовні причини ії̈ спонукали і які богословські засади стали її фундаментом? Як ідентифікувалися й виявлялися елементи богословської системи Реформації в її різних формах?

Аналіз досліджень і публікацій. Богословські принципи протестантизму часто ставали предметом як релігієзнавчого, так і богословського аналізу. Одним із найвідоміших дослідників богослов'я різних груп Реформації є Алістер МакГрат (Богословская мысль Реформации), також варто назвати Timothy George (Theology of the Reformers), Jim Packer (Sola Scriptura), R. C. Sproul (Sola Scriptura) та інших. Релігієзнавчий аналіз протестантської герменевтики здійснювали О. В. Арапов (Герменевтика сакрального текста), М. Панченко (Новая Реформация).

Також аналізу богословських основ, сформульованих як 5 Sola, присвячено чимало конфесійних досліджень. Наприклад, лютеранський теолог Дж. Корзін (Corzine J. The Source of the Solas), А. Тихомиров (Протестантский принцип); євангельські богослови М. Черенков (Європейська реформація) А. Пузинін (Традиция евангельских христиан) та ін.

Мета статті полягає в тому, щоб простежити форми вияву основних богословських принципів Реформації, поширених останнім часом у зв'язку з відзначенням 500-ліття Реформації та відомих як 5 Sola Реформації в різних групах протестантизму.

Виклад основного матеріалу.

Богословські витоки Реформації. Духовна проблема всіх рефрорматорів полягає в конфлікті між реальним станом, у якому вони застали християнство, і тим ідеальним уявленням, яке склалося в кожного 3 них під впливом різних джерел. Основним джерелом для формування ідеалу християнства практично для всіх реформаторів була Біблія як богонатхненне Святе Письмо, яке виявляє Божественне Одкровення про людей, їхню поведінку і про самого Бога. Водночас у кожної епохи й кожного реформатора була власна герменевтична парадигма, певні герменевтичні "окуляри", крізь які він і його богословське оточення читали біблійний текст. Так, діячі середньовічних передреформаційних рухів - Д. Вікліф, Я. Гус, Д. Савонарола та інші - бачили перш за все парадоксальну відмінність морального ідеалу християнства, описаного в Євангеліях і притаманного поведінці самого Христа, від практики життя служителів і мирян сучасної їм католицької церкви. Тому свою діяльність вони спрямовували передусім на виправлення морально-етичної моделі поведінки. Дуже яскраво це демонструє приклад Савонароли, який намагався силоміць реформувати Флоренцію відповідно до його розуміння морального еталону християнства.

На відміну від своїх попередників, Лютер, Кальвін та інші реформатори епохи Просвітництва, читали Біблію з богословських, а не етико-гуманістичних позицій. Вони найбільше переймалися правильним богословським розумінням, а вихідною точкою їхнього богослов'я, на противагу модним тоді гуманістичним принципам, які набували все більшого впливу, було бажання повернути Богові гідне місце у християнстві, зробити християнство богоцентричним, а не людиноцентричним. Центром богословської системи всіх магістерських реформаторів був Бог. Він дає одкровення, якому необхідно безперечно підкорятися (Sola Scriptura), Він виправдовує людину за вірою (Sola fide), Він дає благодать для виправдання людини (Sola gratia), Він $є$ центром усього (Sola Christus, Soli Deo gloria).

Цей підхід разюче відрізнявся від панівної в середньовічній традиції зосередженості на людині. В епоху Середньовіччя основними релігійними питаннями, які хвилювали людей, були не питання про Бога, а питання про себе: як людині спастися від гніву Божого; як людям правильно поводитися, щоб догодити Богові, як будувати свої взаємини з людьми, державою, політикою тощо, аби Бог не гнівався? Тобто християнство було дуже практичним. Церква вчила саме такого християнства, хоча на богословському рівні, безумовно, зберігалася рівновага. На противагу такій відвертій зосередженості на людині, її інтересах і користі, реформатори магістерського напряму, особливо Лютер і рання англіканська традиція (до появи пуританства), явно вдалися до іншої крайності. Для них такі практичні принципи християнства, як правила поведінки людини, відступили на другий план, а не раз про них просто забували. Богоцентричність привела до крайньої форми передвизначення, яка, по суті, перепліталася з фаталізмом. Людина не може нічого зробити для свого спасіння i для свого освячення. Вона навіть не може відкинути Божі дії щодо себе, тому протестантська етика - це форма вияву божественної благодаті до людей, визначених на спасіння, які можуть спокійно жити й тішитися своїм обранням. Вони спасенні, і їм нічого не нашкодить. Пізніше ця крайність призвела до появи пуританського руху в Англії, який вдався до протилежної крайності - визначення обрання на спасіння за зовнішньою, часто лицемірною фарисейською поведінкою, а в Німеччині - до більш розсудливого й поміркованого пієтизму.

Намагання повернути християнському богослов'ю богоцентричність було глибинною платфрормою магістерської Реформації, що не могло не вплинути на богословські інтенції іншого крила європейської Рефрормації - радикальної Реформації'. Але, на відміну від високоосвічених класичних реформаторів, у русі радикалів переважав малоосвічений нижчий клас європейської спільноти (селяни, ремісники, дрібні буржуа). Їхня герменевтична система в тлумаченні Біблії була більш бук-

\footnotetext{
1 Цей термін став особливо популярним серед дослідників Реформації завдяки монументальній праці Джорджа Хастона Вільямса "Радикальна Реформація" [36].
} 
вальною і приземленою. Вона будувалася швидше на христоцентризмі, ніж на богоцентризмі. Христос був ближчим, зрозумілішим і доступнішим, ніж трансцендентний Бог томізму чи августинізму. Тому богословські принципи набули в цьому русі інших акцентів, які гармонійніше поєднували суверенну божественну благодать і людські зусилля в ії прийнятті. Указані відмінності в герменевтиці і в богословських акцентах магістерської та радикальної Реформації вели до різного розуміння гасла, відомого сьогодні як 5 Sola.

Що таке 5 Sola (Quinque sola)? У другій половині XX ст. загальнопоширеною думкою стало популярне твердження, що в основі протестантської теології лежить 5 основних принципів, висловлених латиною у формі фраз: Sola Scriptura ("Тільки одним Писанням"), Sola gratia ("Тільки однією благодаттю"), Sola fide ("Тільки однією вірою"), Solus Christus ("Тільки Христос"), Soli Deo gloria ("Тільки Богу слава"). Офіційним документом, який гучно заявив про 5 Sola, стала так звана Кембриджська декларація, ухвалена 20 квітня 1996 р. на зустрічі Альянсу сповідуючих євангелікалізм (The Alliance of Confessing Evangelicals) у Кембриджі (Масачусетс, США)². Енциклопедія євангелікалізму пише про цю подію так: "Декларація містить заяву консервативних євангеліків, які хочуть виправити певні постулати Реформаторського богослов'я" [17, с. 102]. Ïї підготували 14 відомих реформатських і лютеранських церковних діячів і богословів (підписали понад сотня служителів). Суть декларації полягає в заклику покаятися у зв'язках зі світом і його культурою, в ерозії християнських доктрин та інших помилках, які ввійшли в церкву. Опис кожного Sola закінчується закликом повернути основні історичні доктрини йзапереченням їхніх протилежностей.

Власне Декларація, укладена в критичних тонах щодо католицької, харизматичної та постмодерністської традицій, була ініційована книгою "Немає місця для Істини, або Що сталося з євангельським богослов'ям" [35] Д. Велса і намагалася віднайти історично адекватну форму для реформатського фундаменталізму. Проте, незважаючи на полемічний характер, виявлений швидше в інтенціях, аніж у заявах, статті-твердження, як і статті-заперечення, сформульовано настільки загально, що під ними легко можуть підписатися євангельські богослови найрізноманітніших позицій, від лібералів до фундаменталістів, у тому числі євангельське крило католицької та православної церков. У цьому сенсі 5 Sola можна вважати вдалим каркасом богослов'я Реформації. Хоча автори Декларації думали швидше про відокремлення, ніж про об'єднання.

5 Sola стали сучасним своєрідним лого чи метатекстом для демонстрації вчення Реформації. Вони не стільки розкривають саме богослов'я протестантизму, скільки $є$ ознаками чи сигнальними маячками, які описують це богослов'я. Ще до середини XX ст., в епоху домінування картезіанського мислення, богослови воліли описувати свої погляди у формі чіткої структуризації, логічної послідовності і стандартної методології наукового-пізнавального процесу епохи Просвітництва. Спадкоємцем цієї традиції стало все ще модне у слов'янських країнах схоластичне, так зване "систематичне богослов'я". У рамках цієї системи ідеї викладено послідовно й організовано. Наприклад, як учення про джерела богослов'я, про Бога, про Біблію, про людину, про церкву та ін. Але сучасній людині важко й нецікаво слухати й читати систематику. Вона звикла до яскравих образів i

2 Див. повний текст Кембриджської декларації на сайті The Alliance of Confessing Evangelicals [19]. простих символів. Настала епоха "планшетної" цивілізації, тому богослов'я Реформації запропоновано у формі слоганів і яскравих зорових образів. Не випадково богослов'я Реформації подано за допомогою популярного слогана 5 Sola.

3'явився цей метатекст зовсім недавно, лише у XX ст., хоча більшість протестантів (і не тільки протестантів) упевнена, що ці Sola було сформульовано 500 років тому у працях Лютера і Кальвіна. Але лютеранський служитель Я. Корзіне (Jacob Corzine, Concordia Theological Seminary) продемонстрував у своєму есе [23, с. 67], що не існує стандартного списку всіх Sola і найчастіше вони наявні в реформаторському богослов'ї приховано, неявно, у різних джерелах їхні переліки перекривають і доповнюють один одного. Із праць відомих німецьких лютеранських богословів Е. Юнгеля (Eberhard Jüngel), М. Бейнткера (Michael Beintker) та інших, Я. Корзіне виділив 7 Sola: sola gratia, sola fide, sola scriptura, solo verbo, solus Deus, solus Christus, sola experiential. Проте, більшість авторів вважає, що лютеранське богослов'я історично описане тільки трьома Sola - "Писання вище за традицію", "віра вища за діла", "благодать вища за заслуги" (Sola scriptura, fide, gratia). Так було подано лютеранське богослов'я у збірці статей, виданих 1916 р. і присвячених 400-річному ювілею Реформації ${ }^{3}$.

Важливо відзначити, що всі Sola були спрямовані (i до цього часу використовуються) найчастіше проти спотворень, які практикувала в XVI ст. католицька традиція, хоча офріційне богослов'я Августина, Ансельма Кентерберійського й Томи Аквінського фрактично не заперечувало ці Sola й у ньому всі їх можна знайти. Але практичне життя того часу було дуже далеким від богослов'я і далеким від ідей, які описують ці ознаки.

Sola Scriptura - основа богословської системи. Щоб зрозуміти, чому саме ці принципи стали богословськими знаками Реформації, необхідно згадати, що світоглядною базою та життєвою установкою практично всіх ресрорматорів XVI ст. була ідея ad fontes ("назад до джерел"). Це був час відкриття того, що було вже відкрито в часи античності. 3 релігійного погляду це означало повернення до біблійних текстів і ранньої патристичної традиції. Реформатори всіх напрямів одностайно вважали, що найкраще оновити християнство можна, лише повернувшись до ранньоапостольського періоду й до вчення Ісуса Христа. 3 методологічної точки зору цю ідею ніхто ніколи не обґрунтовував, уважаючи її самоочевидною ще з часів Євсевія Кесарійського, який указував, що істина традиція була в церкві від початку, а все, що з'явилося пізніше - тільки спотворення і єресь. Широко відома його максима, що "Церква не має історії. Історію має тільки єресь". Тому немає нічого дивного в тому, що ідеал першохристиянства став моделлю для Реформації. Способом повернення християнства до початку став принцип Sola Scriptura, який відігравав і відіграє досі роль головного інструментального принципу в богослов'ї всіх гілок протестантизму. Цим способом реформатори сподівалися відсікти й побудувати "правильне християнство".

Цей принцип означав, що тільки і єдино Святе Письмо $€$ абсолютно надійним джерелом богопізнання, тому що його дав Бог і воно є Словом самого Бога, утіленим у тексті.

Спочатку, у часи Рефрормації, цей принцип був спрямований проти спотворення християнської доктрини і практики, яких дотримувалися в Західній Європі. Наприклад, практика індульгенцій, шанування святих мо-

\footnotetext{
3 Детальніше див. статтю Prof. Engelder "The Three Principles of the Reformation" [33].
} 
щей, звертання до Діви Марії з титулом Богоматір, молитви до святих про захист та ін. - усе це пояснювалося церковною традицією, а не Писанням.

Реформатори, звичайно, визнавали Боже одкровення в природі, історії й особистому одкровенні, даному Духом Святим. Також вони не були настільки наївними, щоб уважати, що Біблія впала з Неба готовою чи з'явилася в результаті диктування божественного Автора. Усі лідери Реформації були богословськи високо освіченими людьми, і вони добре розуміли сутність біблійного богонатхнення, знали історію Біблії і процес її канонізації. Вони знали, що до середини I ст. не існувало записаних новозаповітних текстів, а була тільки усна традиція, але, як відомо, така форма передачі Божественного Слова дуже ненадійна зі змістового погляду. Інакше кажучи, усна традиція в плині часу здатна спотворити початкову звістку. Тому Дух Святий потурбувався про те, щоб через історично дуже короткий проміжок часу традицію було зафіксовано у вигляді чотирьох незалежних свідчень (Євангелій - життєписів Ісуса Христа), а також у формі послань Апостолів та інших новозаповітних книг. Так з'явився писемний критерій усної традиції й історія довела важливість такого критерію, продемонструвавши, як за століття люди здатні спотворити початкову керигму з найкращих мотивів. Тому перша хвиля протесту була спрямована на Святе Передання.

Проте реформатори не протестували проти всього Передання чи проти традиції взагалі. Вони рішуче виступили лише проти тієї його частини, яка не узгоджувалася з Писанням чи прямо суперечила Йому. У католицькій церкві побутувала (й існує досі) думка про два рівних джерела божественного одкровення - Писання і Передання: "Церква, якій довірено поширення і тлумачення Одкровення, черпає свою впевненість у всьому відкритому не лише з одного Святого Письма. Тому і Писання, і Передання потрібно визнавати й шанувати з однаковим почуттям благоговіння і поваги" [11]. Саме проти Передання як додаткового джерела одкровення виступили редорматори, але ту частину передання, яка історично сформувалася в загальнохристиянській традиції як герменевтичне загальноцерковне передрозуміння біблійного тексту, реформатори не відкидали. Тому "Тільки Писання" не означає цілковите заперечення традиції, а відкидання її додаткової частини.

Радикальні реформаційні групи були більш послідовними у відкиданні Передання. А. МакГрат відзначає, що вони стверджували: "...Цвінглі зрадив власні реформаційні принципи. Він проповідував одне, а практикував інше. Хоча Цвінглі відкрито заявляв про свою схильність до принципу Sola Scriptura, Гребель стверджував, що він зберіг низку практик, у тому числі хрещення немовлят, близький зв'язок Церкви з Магістратурою й участь християн у війнах, які не дозволені і не освячені Писанням. У руках таких радикальних мислителів принцип Sola Scriptura набув крайнього значення: peформовані християни почали вірити лише в те і практикувати лише те, чого явно вчило Писання" [8, с. 60].

Такими групами радикалів стали швейцарські анабаптисти, меноніти, а пізніше баптисти й інші представники пізньопротестантських течій. Усі вони заперечували хрещення немовлят як практику, не підтверджену Писанням, зв'язок реформаторів із державою, а також часто наполягали на непротивленні злу й пацифрізмі.

3 точки зору східної християнської традиції, яка не визнає теорії двох джерел і не відокремлює Писання від Передання, богословська інтерпретація принципу Sola Scriptura видається складнішою. Уміщуючи Писання в центр загального передання, східна традиція змушує визнати радикальне формулювання принципу Sola
Scriptura, тобто наполягати на запереченні всього, що явно не підтверджене Писанням, роблячи акцент на понятті "явно". Але ця заява ставить перед читачем Писання суто герменевтичне завдання - зрозуміти явний сенс і значення біблійного тексту.

Переважна більшість представників слов'янської радикальної реформатської традиції, тривалий час відірвана від світового євангельського богослов'я через "залізну завісу", досі дотримується принципу, названого деякими дослідниками ${ }^{4}$ принципом "наївного реалізму". Це глибоко протестантська ідея того, що кожен християнин, який читає Біблію, може зрозуміти їі сенс самостійно. Базується це переконання на уявленні про люблячого Бога, який захотів відкрити Свою волю людям і зробив це найбільш доступним і непорушним чином за допомогою Святого Письма. Отже, Писання, тобто слова Бога, звернені до людей, повинно бути чітко викладеним і зрозумілим кожному. Звідси походить уявлення, що, базуючись лише на здоровому глузді, отримувач може правильно зрозуміти, що хоче сказати йому відправник послання - Бог. Звичайно, "наївний реалізм" не передбачає цілковитої відсутності герменевтики, але він наполягає на інтуїтивній герменевтиці, якою люди користуються в повсякденній інтерпретації писемних, усних текстів чи подій.

Зрозуміло, що такий погляд загрожує герменевтичним свавіллям, коли кожна людина може по-різному читати й розуміти Святе Письмо. Перші реформатори швидко зрозуміли це, зіткнувшись із найрізноманітнішими, іноді фантастичними тлумаченнями Біблії. Щоб сорормувати цільну інтерпретацію Біблії, Лютер, Кальвін та інші отці-реформатори почали створювати межі, в яких варто було розуміти біблійний текст. Цими межами стали катехізиси і Сповідання віри (кредо). А. МакГрат пише: "За іронією долі рух, який надавав такого значення Писанню, згодом почав відмовляти своїм менш освіченим членам у доступі до Писання, побоюючись, що вони можуть неправильно його витлумачити (інакше кажучи, розтлумачити його не так, як магістерські реформатори). Наприклад, за шкільними правилами Вюртемберзького герцогства, лише найздібніші учні отримували право вивчати Новий Заповіт у випускному класі за умови, що навчання відбуватиметься грецькою і латинською мовами. Решта повинна була замість цього читати "Малий катехізис" Лютера" [8, с. 192].

Радикальна Реформація пішла іншим шляхом, намагаючись обмежити наївний реалізм чи екзегетичний оптимізм, як його іноді називають. Сповідання віри, катехізиси чи інші писемні джерела тлумачення не були дуже популярними в цій групі. Їхнім головним інструментом стала колективна чи громадська герменевтика, яка дозволяла громаді віри коректувати своїх лідерів і спільно випрацьовувати загальноприйняте розуміння біблійних пасажів.

С. Мюррей, аналізуючи анабаптистську герменевтику [30, с. 403-423], виділяє в ній 6 компонентів, серед яких найбільш визначальним уважає те, що Біблія - самоінтерпретувальна книга, тобто християни можуть упевнено розуміти Писання. Це пов'язано з другим анабаптистським принципом: Дух Святий - інтерпретатор Писання, тобто завдяки особистій присутності Духа Святого в серці кожного вірянина можливо реалізувати принцип екзегетичного оптимізму. Водночас ще одним принципом, тісно пов'язаним із попереднім, $є$ уявлення про конгрегаціоналістську (громадську) герменевтику. Інакше кажучи, якщо Біблія є текстом, створеним

4 Детальніше див. Поль Рікер "Конфликт интерпретаций: очерки о герменевтике" [12]. 
для громади і сформованим у громадах, то й розуміння цього тексту може й повинно здійснюватися в громаді. Наступним важливим принципом, який доповнює попередні, $є$ герменевтика послуху. С. Мюррей відзначає, що легітимація самих інтерпретаторів і перевірка правильності їхнього тлумачення Писання відбувається лише, якщо їхнє практичне життя і їхні висновки відповідають чіткому розумінню тексту. Він робить висновок про це на основі праць багатьох анабаптистських авторів, але вказує, що на практиці цей принцип реалізовувався аж ніяк не завжди. Два додаткових принципи анабаптистської герменевтики С. Мюррей формулює як христоцентризм (Христос - центр герменевтичного процесу) і перевага Нового Заповіту над Старим, тобто тлумачення Старого Заповіту необхідно здійснювати з погляду Нового.

Сучасні виклики принципу Sola Scriptura. Починаючи з епохи модернізму, принцип "Тільки Писання" опинився перед лицем чисельних викликів. Деякі з них породжені гіперкритикою біблійного тексту, але до інших варто поставитися досить серйозно.

Насамперед варто відзначити, що цей принцип викликав серйозну поляризацію в самому євангельському богослов'ї. З'явилася велика група мислителів, які почали серйозно критикувати поняття богонатхненності Біблії, що відповідно викликало полеміку навколо слогана Sola Scriptura. Зазвичай цю групу часто називають ліберальними богословами. Їх поява не могла не викликати фундаменталістської реакції і виникнення відповідного руху, який твердо тримається лютерівського розуміння богонатхненності й застосування принципу Sola Scriptura. Між цими двома групами знаходиться широкий простір, який займають так звані євангеліки (evangelicals), які намагаються примирити виклики сучасності $з$ класичним розумінням Бога.

Багато дослідників відзначають, що Лютер, відкривши двері для Реформації, мав стикнутися з фактором реформації його власних наріжних принципів І. Мейєндорф, говорячи про значення Реформації з православної перспективи, стверджує: "XIX століття стало свідком розвитку біблійного критицизму: протестантські вчені відкрили, а протестантські богослови усвідомили, що Біблія $€$ великою мірою людським документом. Насправді ж, зародок цієї проблеми був уже в критичному ставленні Лютера до "солом'яного послання" апостола Якова. Так чи інакше, сучасний біблійний критицизм викликав справжню революцію у великій частині протестантського світу" [9]. Історико-критичний метод у широкому розумінні, справді, став серйозним викликом для Sola Scriptura. Фундаменталістське крило відповіло на цей виклик повторенням формул XVI ст., наполягаючи на сприйнятті їх вірою. Так, один із прибічників класичного реформаційного підходу, Д. Пакер (J. I. Packer) пише, що Писання: "едине Боже Слово в

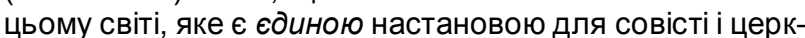
ви, єдиним джерелом істинного знання про Бога і Його милість і єдиним правдивим суддею будь-якого вчення і свідчення церкви, як у минулому, так і сьогодні" [31, с. 48-49]. Це типовий приклад уявлення, яке часто зустрічається і в слов'янському євангельському русі, що найкращою відповіддю на сучасні виклики буде лозунгове повторення правильних старих слів. У XX ст. з такими лозунгами сперечалися, в XXI ст. їх просто не помічають.

Багато євангельських богословів, бачачи методологічні недоліки історико-критичного методу, але не обмежуючись простим повторенням старих фрормул, почали розробляти нові герменевтичні підходи, побудовані на інакших принципах, ніж ті, які використовува- ли ліберальні чи постліберальні богослови. Цікавим прикладом нової герменевтики може бути канонічний підхід Б. Чайлза ${ }^{5}$, який умисне відмовився аналізувати справжність авторства чи історичних обставин кожної книги, а займається тлумаченням канону в його завершеній формі. Або можна відзначити цілу групу нових герменевтичних систем, поданих у книзі "Чотири погляди на рух від Біблії до богослов'я" [28].

Іншим серйозним викликом для Біблії стали досягнення наук, перш за все природничих, які в епоху модернізму зайняли фактично місце релігії. Сайєнтизм (інша назва сцієнтизм) часто пропонує певні погляди, які можуть не співпадати, а іноді й суперечити біблійним. Як бути в таких випадках? Звичайно, є наукові заяви, які $\epsilon$ тільки гіпотезами, і пізніше їх замінюють інші гіпотези, що дає можливість оголосити деякі антибіблійні висновки недостовірними чи недостатньо доведеними. Однак, як зазначив В. Панненберг, "якщо теологія i світські науки роблять кардинально різні заяви про світ, людину та історію, то питання про те, яка з цих заяв $€$ правдивою, не може залишатися без відповіді" [32, с. 308]. На цей виклик євангельське богослов'я відповіло створенням цілої системи науково-апологетичних центрів ${ }^{6}$, багатьма апологетичними публікаціями ${ }^{7}$. Але слід підкреслити, що сила цього виклику в III тисячолітті значно знизилася через розвиток загальної постмодерністської критики науки та ї̈ досягнень, тому актуальність науково-апологетичних зусиль $є$ невисокою.

Найбільш серйозним у наш час викликом принципу Sola Scriptura є епістемологічні питання постмодерністської свідомості. Перш за все, це загальне гносеологічне питання, яке стало сьогодні надбанням широких мас, а не тільки фрілософів. Його можна сформулювати так: "Як я можу знати, що Біблія єдина богонатхненна книга? I як я взагалі можу щось знати про цей світ і про себе?". Сучасна теорія пізнання, відмовившись від наукоцентризму, від жорстких нормативних вимог до процесу пізнання, від критеріїв, які відокремлюють знання від незнання, розвиваючи герменевтику підозри й одночасно протилежну посткритичну герменевтику довіри, утративши об'єктивну реальність і роблячи акцент на ірраціональних способах пізнання і розуміння, - стала хаотичною і багатовимірною. Це призвело до масових критичних випадів на адресу біблійного тексту, але не 3 точки зору його правдивості або науковості, а з погляду його епістемологічного значення.

Багато хто вважає, що потрібна "неймовірна інтелектуальна наївність", щоб беззастережно визнати принцип "Тільки Писання" і довіритися Духу Святому, який роз'яснює текст. Однак навіть визнаючи ці, відкрито полемічні заяви, сучасна біблійна епістемологія може будуватися як простір для діалогу, де зустрічаються різні погляди. Дехто може спиратися на традицію і текст, відповідаючи на питання про підстави пізнавальної діяльності, інші на інтуїцію й безпосереднє феноменологічне розуміння, деякі на досвід і розум, але з усім цим константа Sola Scriptura залишається головною міцною основою в хиткому плюралістичному світі Постмодерну.

\footnotetext{
5 Про так званий "канонічний" підхід Бреворда Чайлдза див. Childs Brevard S. "The Book of Exodus: A Critical, Theological Commentary" [21] та Childs B.S. "Biblical Theology in Crisis" [20]. ${ }^{6}$ Наприклад, див. сайт Християнського науково-апологетичного центру.

${ }^{7}$ Наприклад, серія книг ББІ "Богословие и наука" (сайт БіблійноБогословського Інституту святого апостола Андрія [3]) або Енциклопедія християнської апологетики - Geisler N. L. "Baker encyclopedia of Christian apologetics" [24].
} 
Ми гадаємо, що в наш час напади на цей принцип часто пов'язані з його неправильним розумінням. У повсякденній свідомості "Тільки Писання" нерідко сприймається як відкидання всього, крім Біблії. Д. Форсен (D. Thorsen) у статті [34], присвяченій Sola Scriptura, указує на сучасні помилки в його розумінні. Ці помилки можна підсумувати як заяву, що не затверджує принцип "Тільки Писання":

1) Sola Scriptura не говорить, що в Біблії містяться знання з усіх питань. Тому не варто шукати в ній наукової інфрормації, ідеалів соціального устрою суспільства, повноти інформації взагалі;

2) також цей принцип не говорить, що в Біблії міститься вся повнота релігійних знань. Зрозуміло, що вона і не повинна містити всю повноту божественної Істини, їі мета зовсім інша (див. Ів. 21: 25);

3) цей принцип не заперечує участі служителів церкви в тлумаченні й донесенні біблійного тексту до одержувача;

4) Sola scriptura не означає, що Слово Боже не звучить в інших формах. Цей принцип вказує, що Писання служить народу Божому як повна й вища форма Божественного одкровення;

5) заява "Тільки Писання" не тягне за собою відмови від абсолютно всіх церковних традицій. Зрозуміло, що $€$ деякі традиції, які бажані Богу й корисні Церкві. Але Sola Scriptura означає, що Писання є вищим авторитетом і владою, яка повинна перевірити будь-які традиції, незалежно від того, наскільки вони давні чи авторитетні;

6) Sola Scriptura не $є$ запереченням ролі Святого Духа в тлумаченні Писання, але будь-які одкровення перевіряються біблійним текстом.

Sola Gratia - центр богословської системи Люmера. Принцип "Тільки благодать" став для Лютера (а пізніше для всіх реформаторів магістерського напряму) першою вихідною точкою, яка привела його до нового погляду на християнське богослов'я. Суть його в тому, що людина спасеться тільки благодаттю Божою, як Иого милосердною дією, а не своїми заслугами перед Богом або людьми. Саме це питання - як людині спастися - було початком богословських пошуків реформаторів, що випливають з ідеї спасіння за благодаттю. Богослов'я виправдання як визнання грішника абсолютно невинним стало головним, системотвірним принципом лютерівської системи.

Ідея Sola Gratia була спрямована проти загальноприйнятого в середньовіччі уявлення про те, що грішну людину чекає немилосердний суд Божий і спасіння можливе тільки в церкві. Це, безумовно, загальнохристиянська ідея, заснована на новозавітних текстах, але в дореформаційний період висновки 3 неї артикулювати дуже неточно. Простий народ і більшість рядових служителів сприймали спасіння в категоріях турботи церкви про грішників, яка виявляється в тому, що вони отримують благодать через церковні канали - участь у таїнствах, прилучення до понадналежних (лат. Supererogatoria opera) заслуг святих, як це пояснив П. Ламбардський, та інші церковні засоби.

"Тема виправдання була улюбленою темою суперечок і міркувань у схоластичному богослов'ї, але за тисячу років, що передували Реформації, офріційна церква чомусь жодного разу не висловлювала авторитарної думки щодо цього. Найважливіша тема Нового Заповіту з огляду на низку причин не отримала чіткого і виразного вияву, а богословські мудрування навели неймовірно велике число висловлювань із цього приводу. Тому на питання, яке завдяки гуманізму почало звучати не колективно, а індивідуально, особистісно: "Що я пови- нен зробити, щоб спастися?" - представники церкви не могли дати чіткої й однозначної відповіді" [13, с. 292]. Такий стан призводив до богословської невизначеності, й у свідомості пересічних християн складалося уявлення, що спасіння треба заробити добрими справами і правильною поведінкою. Бунт Лютера був саме проти такої концепції виправдання, яка робила занадто великий наголос на ролі церкви в питанні спасіння, хоча в офріційному католицькому богослов'ї виправдання було описане більш точними біблійними категоріями.

Принцип Sola Gratia, на перший погляд, підкреслює монергізм у питанні спасіння, тобто в цьому питанні немає і не може бути ніякої співпраці між Богом і людиною, що стає зрозумілим, якщо згадати розвинену ще Августином доктрину повної й остаточної зіпсованості людини в результаті первородного гріха. Однак Лютер і його богословські послідовники не розробляли теми прийняття благодаті, яку подає Господь грішнику. Типово передбачалося, що грішник прийме благодать Божу без будь-якої можливості її відкинути. Це було зрозуміло з абсолютного фраталізму Лютера, який не раз висловлювався й писав про рабство людської волі, хоча в нього ідея абсолютного суверенітету Божого й приречення людини з усіма ії діями не стояла в центрі богослов'я, як це стало пізніше в Кальвіна.

Анабаптисти й уся армініанська традиція цілком погоджується з повною залежністю від Божої благодаті. У цьому сенсі їх цілком можна зарахувати до моноргістської течії, але вони інакше, ніж класичні реформатори, ставлять питання про прийняття благодаті. Четвертий пункт Ремонстрації, офіційної декларації армініанства, говорить: "Благодать Божа є початком, розвитком і завершенням всього доброго, тому навіть відроджена людина не може ні помислити, ні здійснити нічого доброго, ні протистояти жодній спокусі на зло без допомоги благодаті, яка йде попереду (тобто передує), пробуджує і сприяє. Тому всі добрі справи і спонукання до добра потрібно приписувати благодаті Божій. Але за своїм поводженням благодать не є нездоланною; адже написано про багатьох, що вони були проти Духа Святого" [18, с. 268-269]. У цьому пункті цілком очевидно виявляється принцип "Тільки благодать", але водночас дається більш довершене уявлення про роль i відповідальності людини в прийнятті божественної благодаті. У цьому полягає серйозна відмінність між магістерською та радикальною Реформацією, яка завжди підкреслювала відповідальність людини у прийнятті благодаті.

Варто також зазначити, що доктрина виправдання взагалі не відіграє значної ролі в східному богослов'ї, яке оперує не стільки юридичною термінологією в питанні спасіння, скільки онтологічною, кажучи про уподібнення до Бога. Тому дискусії навколо принципу Sola Gratia мало зрозумілі східній богословській свідомості. Вона знаходиться ніби поза сферою цієї суперечки.

Sola Fide - практичний принцип Реформації. Цей принцип з'явився як заява, спрямована не стільки проти богословських, скільки проти звичайних, але панівних і досі уявлень, що спасіння можна отримати за сукупність добрих справ. Багато людей вважали й досі вважають, що Бог під час останнього суду буде зважувати життя кожної людини й аналізувати кількість її добрих справ і гріховних провин. Якщо кількість добрих справ переважить кількість гріхів, буде відкрито шлях до раю, якщо навпаки - у пекло. Ця спрощена картинка, яка мало відповідає загальнохристиянському (і біблійному) вченню, звичайно, викликала протидію з боку мислячих людей. 3 цієї причини відносини між вірою i справами стали пробним каменем, на якому практич- 
но можна було перевірити основний принцип виправдання - Sola Gratia. Тому Лютер часто говорив, що віра або справи є статтею, яка виявляє "стоїть чи падає Церква" (лат. Articulus stantis et cadentis ecclesiae).

Ідею Sola Fide справді важко втримати в динамічній рівновазі. Апостол Павло явно вказує на спасіння за вірою (Рим. 3: 28) і наводить приклад віри Авраама: "Авраам "був увірував в Бога, - і це залічено за праведність йому" (Гал. 3: 6). Але інший Апостол, Яків, наводить цей же епізод із життя Авраама, говорячи про справи: "Авраам, отець наш, - чи він не з діл виправданий був, як поклав був на жертівника свого сина Іаака? Чи ти бачиш, що віра помогла його ділам, і вдосконалилась віра із діл?" (Як. 2: 21-22). Віра й діла справді пов'язані у Святому Письмі, але іноді їх штучно розривають. Багато хто вважає, що Лютер теж зробив таку помилку й відірвав віру від справ. Відомо, що він категорично не погоджувався з Яковом, уважаючи його послання "солом'яним", і не визнавав його чіткої заяви, що справи підтверджують наявність віри. У будь-якому разі, Л. Шестов, аналізуючи шлях Лютера до піднесення віри над справами, погоджується 3 католицьким дослідником Деніфле, що Лютер зі слабкості проголосив виправдання тільки вірою. Він пише: "Усвідомлення неможливості виконати не тільки покладені на себе чернечі обітниці, а й звичайні заповіді було початком Лютерового відступництва". Далі автор говорить, що Лютер "хоче бути слабким, грішним, несправедливим, неосвіченим, дурним - він хоче позбутися усіх якостей, усіх чеснот" [15, с. 380]. I це виявилося в наступній практиці і самого Лютера, і лютеран, які вважали, що головне - правильні доктрини, правильна віра, а не правильне життя. Лютер пише: "Отже, давайте вчитися якомога ретельніше відокремлювати Христа від всіх справ, чи то справи благі, чи ганебні, від усіх законів, чи то закони божественні, чи людські, і від усіх розтривожених сердець" [7, с. 544]. Д. Мережковський цитує Лютера: "Ми так само погано жили, як римські католики. Але ми боремося не за життя, а за вчення. Ось чого не зрозуміли ні Вікліф, ні Гус, нападаючи тільки на погане життя католиків" [10, с. 34]. Хоча в лютеранських катехізисах та інших офріційних документах йдеться про добрі справи, але постійне підкреслення, що християнство не пов'язане зі справами, на практиці часто призводить до повного нехтування особистою святістю й акцентування на своїй свободі праведної чи неправедної поведінки ${ }^{8}$.

Таким чином, віра в багатьох представників магістерської реформації стає тільки умоглядним переконанням у певних доктринах. Наприклад, упевненість, що Христос - це історична особистість, що Він справді помер і воскрес тощо. Але віра як знання певних фактів або вчень порівнюється в Писанні з вірою, яку мають навіть біси (Як. 2: 19). Тому представники радикальної Реформації, повністю погоджуючись із принципом Sola Fide, розуміли феномен віри інакше. Вони завжди наполягали на тому, що віру повинні доводити особисте праведне життя й добрі справи, підкреслюючи, що "віра без діл мертва". Тому один із найглибших дослідників анабаптистських руху, Г. Бендер, писав: "Для анабаптистів першорядне значення мало "справжнє християнське життя", тобто життя, засноване на словах і житті Христа. Вони вважали, що реформатори, незважаючи на свої заяви, не навертали народ на істинне покаяння, відродження і християнське життя. Метою реформації була віра, і це було правильно, але недостатньо, бо, на їхню думку, без оновленого життя віра є лицемірною" [2, с. 177].

8 Як це показано у фільмі Інгмара Бергмана "Причастя" [4].
Тому анабаптисти надавали такого серйозного значення церковній дисципліні і практикували відлучення за явні гріхи. Шлайтхаймське віросповідання ранніх мирних анабаптистів говорить: "Відлучення необхідно застосовувати до всіх, хто присвятив себе Богові і вирішив виконувати Його заповіді, хто був хрещений у тіло Його і називається братом або сестрою і хто все ж іноді помиляється i, захоплений зненацька, впадає в неправедність і гріх (або ж сатана опановує його через неуважність)" [16]. Відлучення або інші форми церковної дисципліни повинні були відокремити тих, у кого віра не виявлялася в практичних справах. Таким чином, саме в різному розумінні суті поняття "віра" полягала одна 3 найважливіших богословських відмінностей магістерської та радикальної Реформації.

Solus Christus, Soli Deo gloria - спрямованість i цілепокладання протестантського богослов'я. Уважається, що перший раз ці два додаткових Sola з'явилися в книзі "Церква і світ" [29], виданій за редакцією І. Метзен 1965 р. Обидва принципи вказують на мету й сенс існування богословської системи реформаторів і визначають ї̈ спрямованість.

Принцип Solus Christus ("Тільки Христос") часто розуміють, передусім, у критичному контексті, як указівку на необхідність відмовитися від всіх інших посередників між Богом і людьми, оскільки за виразним біблійним вченням лише Христос $є$ єдиним Заступником і Первосвящеником, який стоїть перед Богом за народ і заступається за грішників. Він єдиний Глава церкви, Який розпоряджається всіма їі благами. Отже, усі допоміжні побудови, зроблені історичними церквами (заступницька допомога Діви Марії, святих та ін.) необхідно усунути.

Також цей принцип часто розуміють як заперечення особливого класу священства (сакердоталізму) як служителів, які тільки можуть здійснювати священнодії в громаді (хрещення, Євхаристію та ін.), несучи апостольську спадкоємність. Ідею "Тільки Христос" сприймають як можливість кожному члену громади безпосередньо приходити до Бога через Христа і здійснювати всі встановлені Ним священнодії. У цьому розумінні також $€$ відмінність між магістерськими і радикальними реформаторами. Хоча всі реформатори заперечують сакердоталізм, але в лютеранстві реально існує окремий клас служителів, які виконують священнодії, і клас мирян або парафріян. В анабаптизмі, особливо в євангельському християнстві слов'янських країн, поділ на клір і священство виражений набагато слабше. У цих групах реально намагаються практикувати принцип загального священства.

Також Sola Christus часто тлумачать у позитивному сенсі, указуючи на христоцентричність у самому Писанні й у доктринальній спрямованості протестантського богослов'я. Як уже зазначалося, магістерські рефоорматори, особливо кальвіністського напряму, завжди підкреслювали богоцентричність на противагу гуманістичним тенденціям людиноцентричності. Це, зокрема, виявляється в їхньому ковенантному богослов'ї, яке підкреслює переважно цілісність Писання, бачачи єдиний заповіт, що виявляється в різних формах. Водночас анабаптистські групи, більше тяжіючи до диспенсаціоналістського богослов'я, завжди підкреслюють важливість Нового Заповіту й наполягають на герменевтичному підході до тлумачення Старого Заповіту винятково з перспективи Нового, указуючи на важливість христоцентричності, а не богоцентричності, підкреслюючи, що люди пізнають Бога тільки через Христа .

Уявлення про христоцентричність на противагу богоцентричності зосереджувало увагу на відмінності Христа від Отця, яка виявилася в боговтіленні. Хоча абсо- 
лютною істиною залишається те, що Христос як одна з осіб Божества абсолютно рівний Отцю, анабаптистська традиція завжди підкреслювала, що Христос не тільки абсолютний Бог, а й абсолютна людина, рівний людям в усьому, крім гріха. Як людина Він показав приклад добровільного послуху, смирення і свідомої покори волі Божій. Говорячи про взаємини Отця і Сина, можна скористатися добре розвиненим у східному богослов'ї поняттям перехорезису як гармонійної, взаємопроникної єдності. Та водночас Христос завжди підкреслював Своє підпорядкування і слухняність Отцю, указував на Свою людську природу, яка знаходиться у вільній згоді з волею Отця. На практичному рівні це виявлялося як розуміння спільних дій Отця і Сина, як відображення цієї ідеальної практики - спільних дій Бога і людини, коли людина стає стороною, яка добровільно приймає, а Бог - дає все в любові.

I нарешті, принцип Soli Deo gloria висловлює ecхатологічне передчуття і сподівання, котре починається вже на землі в безупинній доксології, прославлянні Бога за спасіння, яке Він здійснює, за благодать і за всю Його роботу з доморядництва Царства Божого. Але в цього принципу $є$ також дуже важливий земний вимір, на який звернули увагу протестанти. Будь-яка земна практична діяльність розглядається як та, що здійснюється для слави Божої. Можливо, саме цей вимір став головним пунктом протестантської етики, який сформував дух капіталізму. Так, звичайні земні професії освячувалися і ставали працею для Бога.

Лютер писав: "У шевця, коваля, селянина і в кожного $€$ своє ремесло, посада і справа, і все ж всі вони в однаковій мірі $є$ посвяченими священиками і єпископами; і кожен, виконуючи свою посаду або займаючись своїм ремеслом, зобов'язаний приносити користь іншим і служити їм" [6, с. 16]. Розуміння рядової праці як священного обов'язку абсолютно відрізняється від ставлення до праці в східноправославному контексті, що вплинуло й на слов'янські пізньопротестантські рухи. Т. Коваль, аналізуючи етику праці православ'я, пише: "Впадають в око "непрактичність" православ'я, його "невідсвітний" характер, спрямованість до вищого і вічного. В історії православ'я це іноді супроводжувалося тотальним відкиданням світу і нехтуванням мирськими проблемами, зокрема господарсько-економічними" [5]. Справді, у східній традиції частіше підкреслюється поділ на працю профанну, мирську й працю сакральну, духовну (на межі - чернеча - цілком присвячена Богу). 3 тим слава Єдиному Богу підноситься, звичайно, від церковних форм праці, а не від мирських. Однак принцип Soli Deo gloria змушує переглянути цю позицію.

Висновки - нові Sola. 5 Sola сьогодні широко використовують для опису богословських ознак Реформації. Однак треба враховувати, що протестантизм - це неоднорідне в богословському розумінні явище. У ньому $є$ багато напрямів, але їх можна об'єднати у два основні табори: магістерська реформація й радикальна. До магістерської реформації зараховують класичні форми протестантизму (лютеранство, кальвінізм, англіканство та ін.). До радикального крила зараховують різні групи анабаптизму. 5 Sola добре відображають узагальнену протестантську позицію всіх напрямів, але герменевтика цих п'яти індикаторів богословської системи в різних групах значно відрізняється. Крім того, тлумачення й застосування цих 5 Sola змінювалися із часом. На прикладі Sola Scriptura добре видно, що розуміння цих традиційних "стовпів" Реформації зазнає серйозних викликів, особливо з боку постмодерністських тенденцій сучасного суспільства.

Богослов'я XXI ст. не тільки ставить критичні питан- ня кожному 35 Sola, але і значно розширює cферу їx опису. Багато богословів свідчать, що протестантське богослов'я недостатньо описувати класичними 5 Sola, i пропонують упровадити нові ознаки. Зокрема, М. Глодо в статті "Sola Ecclesia: втрачена реформаційна доктрина" [25] ставить питання про роль церкви в рефрорматському богослов'ї і справедливо вказує, що без указівної церкви ніхто не може розраховувати на виправдання й навіть на спасіння. Місія церкви - показати Христа і донести Писання до сучасних людей.

Інше розширення такого індикатора, як Sola, пов'язане з уточненням поняття "чинна віра". Р. Леонарді пише: "Лютерівський вислів sola fide справедливий, якщо його не протиставляти милосердю, благодійним справам, жертовній любові" [26]. Тому він вважає, що треба додати ще одне Sola - Sola Caritas ("Tільки жертовна любов").

Отже, незважаючи на певну обмеженість, п'ятьма Sola, визнаними масовою свідомістю, цілком можливо описати основні принципи протестантського богослов'я.

\section{ЛТЕРАТУРА}

1. Бевзюк Н. П. Религиозные и церковные основы Реформации / Н. П. Бевзюк // Ученые записки Таврического национального университета им. В. И. Вернадского. - Т. 24 (63). 2011. - № 2 .

2. Бендер Г. С. Анабаптистские принципы / Г. С. Бендер // Менно Симонс и анабаптисты / [под ред. С. Санникова]. Саменкорн, 2012.

3. Библейско-Богословский Институт святого апостола Андрея [Електронний ресурс]. - Режим доступу : http:// standrews.ru/internet-magazin/bogoslovie-i-nauka/

4. Зимний свет (Причастие) Ингмара Бергмана (Winter Light 1963) [Електронний ресурс]. - Режим доступу : https:// www.youtube.com/watch?v=_nWUxirX7pM - Название с экрана (дата обращения: 25.04.2017).

5. Коваль Т. Этика труда православия [Електронний ресурс] / Т. Коваль. - Режим доступу : http://ecsocman.hse.ru/ data/441/176/1217/006_KOVAL.pdf.

6. Лютер М. К христианскому дворянству немецкой нации // Лютер М. Время молчания прошло: Избранные произведения 1520-1526 гг. / М. Лютер ; [пер. с нем., ист. очерк, комментарии Ю. А. Голубкина]. - Харьков : Око, 1994. - 352 с.

7. Лютер М. Лекции по "Посланию к Галатам" / М. Лютер. М. : Фонд "Лютеранское наследие" ; Минск, 1997.

8. Маграт А. Богословская мысль реформации / А. Маграт // Богомыслие. - Одесса, 1994.

9. Мейендорф И. Значение Реформации как события в истории христианства [доклад] ; [Електронний ресурс] / И. Мейендорф // Совещание комиссии "Вера и Церковный порядок", ВСЦ, 10 июля 1963 г., г. Монреаль. - Режим доступу : http:// lib.pravmir.ru/library/readbook/1170.

10. Мережковский Д. С. Реформаторы: Лютер, Кальвин, Паскаль / Д. С. Мережковский. - Томск : Водолей, 1999. $448 \mathrm{c}$.

11. Откровение Божие. Пояснения к тексту "Катехизиса католической церкви" [Електронний ресурс]. - Режим доступу : http://www.teologia.pl/ros/i-o-000.htm.

12. Рикер П. Конфлликт интерпретаций: очерки о герменевтике / П. Рикер. - М. : Канон-пресс-центр, 2002.

13. Санников С. Двадцать веков христианства / С. Санников. - СПб., Одесса : Изд-во ОБС "Богомыслие", 2001. - Т. ІІ.

14. Христианский научно-апологетический центр [Електронний ресурс]. - Режим доступу : http://scienceandapologetics. $\mathrm{com} /$.

15. Шестов Л. И. Sola fide - только верою / Л. И. Шестов. - Рипол Классик, 2013.

16. Шлайтхаймское вероисповедание // Менно Симонс и анабаптисты / [под ред. С. Санникова]. - Саменкорн, 2012. 
17. Balmer R. H. Encyclopedia of evangelicalism / R. H. Balmer. - Louisville, KY: Westminster / John Knox Press, 2002. - 654 p. DOI: $10.1177 / 001452460211400310$

18. Bettenson H. Documents of the Christian Church / H. Bettenson. - Oxford : Oxford UP, 1963. - Pp. 268-269.

19. Cambridge Declaration Heritage and Resources [Електронний ресурс] // The Alliance of Confessing Evangelicals. - Peжим доступу : http://www.alliancenet.org/cambridge-declaration.

20. Childs B. S. Biblical Theology in Crisis / B. S. Childs. Westminster Press, 1970.

21. Childs B. S. The Book of Exodus : A Critical, Theological Commentary / B. S. Childs. - Westminster John Knox Press, 1974.

22. Childs B. S. The New Testament as Canon: An Introduction / B. S. Childs. - Philadelphia : Fortress, 1984.

23. Corzine J. The Source of the Solas : On the Question of Which are the Original Solas / J. Corzine // Corzine J. B. Theology is Eminently Practical : Essays in Honor of John T. Pless; Wolfmueller (Ed.). - Fort Wayne, Indiana : Lutheran Legacy Press, 2012.

24. Geisler N. L. Baker encyclopedia of Christian apologetics / N. L. Geisler. - Baker Books, 1999. - P. 490.

25. Glodo M. J. Sola Ecclesia: The Lost Reformation Doctrine [Електронний ресурс] / M. J. Glodo. - Режим доступу : http:// www.the-highway.com/articleApr06.html.

26. Leonardi R. Sola fide? Sola caritas [Електронний ресурс] / R. Leonardi. - Режим доступу : http://richleonardi.blogspot.com/ 2008/11/sola-fide-sola-caritas.html.

27. McGrath A. Christianity's dangerous idea / A. McGrath // The Protestant Revolution - A History from the 16 th to the 21 st Century. - 2007. - P. 62.

28. Meadors G. T. Four Views on Moving beyond the Bible to Theology / Gary T. Meadors, S. N. Gundry. - Zondervan, 2009.
29. Metz J. B. (Ed.) The Church and the world / J. B. Metz. Paulist Press, 1965. - T. 6.

30. Murrey S. Biblical Interpritation among the Anabaptist Reformers / S. Murrey // Hauser A. J. A History of Biblical Interpretation / A. J. Hauser, D. F. Watson. - Vol. 2: The Medieval through the Reformation Periods. - Grand Rapids, MI : Eerdmans, 2009. - Pp. 403-423.

31. Packer J. I. "Sola Scriptura" in History and Today [Електронний ресурс] / J. I. Packer // God's Inerrant Word: An International Symposium on the Trustworthiness of Scripture / [John W. Montgomery (ed.)]. - Minneapolis : Bethany Fellowship, Inc., 1973. - Рp. 48-49. - Режим доступу : http://www.ccel.us/ godsinerrantword.ch2.html.

32. Pannenberg W. The Crisis of the Scripture-Principle in Protestant Theology / W. Pannenberg // Dialog. - 1963. - T. 2.

33. Prof. Engelder. The Three Principles of the Reformation / Prof. Engelder // Prof. W. H. T. Dau (ed.). Four Hundred Years: Commemorative Essays on the Reformation of Dr. Martin Luther and Its Blessed Results. - Concordia Publishing House, 1916.

34. Thorsen D. Solus Gratia, Solus Fide, and Solus Scriptura : Reforming Protestant Principles to Serve the Present Age [Електронний ресурс] / D. Thorsen. - Oxford Institute of Methodist Theological Studies. - Режим доступу : https://oimts.files. wordpress.com/2013/04/2007-4-thorsen.pdf.

35. Wells D. F. No Place for Truth: or Whatever Happened to Evangelical Theology? / D. F. Wells. - Wm. B. Eerdmans Publishing, 1993.

36. Williams G. H. The Radical Reformation / G. H. Williams. Truman State University Press, 1995.

Санников Сергей,

кандидат философских наук, доктор богословия, старший научный сотрудник,

Центр изучения религий Национального педагогического университета им. М. П. Драгоманова

\section{SOLA РЕФОРМАЦИИ. БОГОСЛОВСКИЕ ПРИНЦИПЫ ГЕТЕРОГЕННОГО ПРОТЕСТАНТИЗМА}

Статья раскрывает религиозно-богословские основания, давшие начало реформационному процессу, с помощью популярных в настоящее время индикаторов, известных как 5 Sola Реформации. Продемонстрированы основные богословские принципы, самоидентифицирующие протестантизм, в сравнении с другими религиозными группами, показано, что герменевтика этих принципов разделяет протестантизм на многие течения, создающие гетерогенность этого религиозного движения. Основное внимание в статье уделено сравнительному описанию каждого из пяти признаков богословской системы в понимании магистерской и радикальной Реформации. Показана история появления 5 Sola и их богословское значение. Наибольшее внимание в статье уделяется базовому формальному принципу всего протестантского движения - Sola Scriptura. Показаны вызовы, которые испытывает этот принцип в постмодернистском обществе, демонстрируется, что означает и что не означает он в современном евангельском движении. Раскрыто значение Sola gratia как систем ообразующего пункта богословской системы лютеранства. Показано различное понимание веры и толкование принципа Sola fide в магистерской и радикальной формах протестантизма. Демонстрируются особенности применения принципов Solus Christus и Soli Deo gloria в восточной и западной христианской традиции.

Ключевые слова: Sola Scriptura ("только Писание"); Sola gratia ("только благодать"); Sola fide ("только верой"); Solus Christus ("только Христос"); Soli Deo gloria ("только Богу слава"); магистерская Реформация; радикальная Рефрормация; Лютер; восточное христианство; западное христианство.

Sannikov Serhii, Candidate of Philosophical Sciences, Doctor of theology, Senior Research Fellow, Center for the Study of Religions, National Pedagogical Dragomanov University

\section{SOLA REFORMATION. THEOLOGICAL PRINCIPLES OF HETEROGENIOUS PROTESTANTISM}

The paper displays the religious and theological foundations, which initiated the reformation process with the help of nowadays popular markers known as 5 Sola of Reformation. It demonstrates the main theological principles which identify Protestantism among other religious groups. But simultaneously the hermeneutics of these principles divides Protestantism into many currents, which forms this religious movement heterogeneity. The main focus of 
the article lays on the comparative description of each of five features of the theological system of Reformed theology in the understanding of masters and radical reformation. The history of formation of 5 Sola and its theological meaning are analyzed as well.

The paper's main interest is focused on the basic formal principle of all the Protestant movement -Sola Scriptura. The author of the article describes the Postmodern society challenges faced by this principle, he demonstrates what it does and what it does not mean in contemporary Evangelical movement. The meaning of Sola gratia as a formation point of Lutheran theological system is exposed, a different understanding of faith and interpretation of the principle of Sola fide in magisterial and radical Protestantism is exposed, the peculiarities of application of the principles of Solus Christus and Soli Deo Gloria in Eastern and Western Christian traditions.

Key words: Sola Scriptura; Sola gratia; Sola fide; Solus Christus; Soli Deo Gloria; Magisterial Reformation; Radical Reformation; Luther; Eastern Christianity; Western Christianity.

\section{REFERENCES}

1. Bevzyuk, N. P. (2011), Religious and Ecclesiastical Foundations for Reformation in Scientific Proceedings of Tavria National University named after V.I. Vernadsky, T. 24 (63), 2. (rus).

2. Bender, G. S. (2012), Anabaptist Principles in S. Sannikov (Ed.). Menno Simons and Anabaptists, Samenkorn. (rus).

3. St. Andrew's Biblical Institute Theological, available at: http://standrews.ru/internet-magazin/bogoslovie-i-nauka. (rus).

4. Bergman, Ingmar (1963), Winter Light, available at: https://www.youtube.com/watch?v=_nWUxirX7pM.

5. Koval, T., Ethics of Orthodox Labour, available at: http://ecsocman.hse.ru/data/441/176/1217/006_KOVAL.pdf. (rus).

6. Lyuter, M. (1994), To the Christian Nobles of German Nation in Lyuter M. The Time of Silence Has Gone: Selected Works 15201526, Kharkov, Oko, 352 p. (rus)

7. Lyuter, M. (1997), Lectures on the Epistle to the Galathians, Moscow, Fond «Lyuteranskoe nasledie».

8. Magrat, A. (1994), Theological Reformation Thought, Bogomyslie, Odessa. (rus).

9. Meyendorf, I. (10 July 1963), Significance of Reformation as an Event in Christian History on Meeting of Commission "Fiath and Ecclesiastical Order", Monreal, available at: http://lib.pravmir.ru/library/readbook/1170. (rus).

10. Merezhkovskiy, D. S. (1999), The Reformers: Luther, Calvin, Pascal, Tomsk, Vodoley, 448 p. (rus).

11. Divine Revelation, The Explanation to the Text "Catechism of Catholic Church", available at: http://www.teologia.pl/ros/i-o000.htm. (rus).

12. Riker, P. (2002), The Conflict of Interpretations: Essays in Hermeneutics, Moscow, Kanon-press-tsentr. (rus).

13. Sannikov, S. (2001), Twenty Centuries of Christianity, SPb, Odessa, Izd-vo OBS «Bogomyslie». (rus).

14. Christian Scientific and Apologetical Center, available at: http://scienceandapologetics.com/. (rus).

15. Shestov, L. I. (2013), Sola fide - by Faith Alone, Ripol Klassik. (rus).

16. The Schleitheim Confession in S. Sannikov (Ed.). (2012), Menno Simons and Anabaprists, Samenkorn. (rus).

17. Balmer, R. H. (2002), Encyclopedia of evangelicalism, Louisville, KY: Westminster John Knox Press, 654 p. DOI: 10.1177/ 001452460211400310.

18. Bettenson, H. (ed.) (1963), Documents of the Christian Church [2nd ed.], Oxford, Oxford UP.

19. Cambridge Declaration Heritage and Resources, The Alliance of Confessing Evangelicals, available at: http://www.alliancenet.org/ cambridge-declaration.

20. Childs, B. S. (1970), Biblical Theology in Crisis, Westminster Press.

21. Childs, B. S. (1974), The Book of Exodus : A Critical, Theological Commentary, Westminster John Knox Press, [repr. 2004].

22. Childs, B. S. (1984), The New Testament as Canon : An Introduction, Philadelphia, Fortress.

23. Corzine, J. (2012), The Source of the Solas : On the Question of Which are the Original Solas in J. Corzine, B. Wolfmueller (Ed.),

Theology is Eminently Practical : Essays in Honor of John T. Pless, Fort Wayne, Indiana, Lutheran Legacy Press.

24. Geisler, N. L. (1999), Baker encyclopedia of Christian apologetics, Baker Books.

25. Glodo, M. J. Sola Ecclesia: The Lost Reformation Doctrine, available at: http://www.the-highway.com/articleApr06.html.

26. Leonardi, R. Sola fide? Sola caritas, available at: http://richleonardi.blogspot.com/2008/11/sola-fide-sola-caritas.html.

27. McGrath, A. (2007), Christianity's dangerous idea, The Protestant Revolution - A History from the 16 th to the 21 st Century.

28. Meadors, G. T. (Ed.), Gundry S. N. (Series Ed.) (2009), Four Views on Moving beyond the Bible to Theology, Zondervan.

29. Metz, J. B. (Ed.) (1965), The Church and the world, Paulist Press, 6.

30. Murrey, S. (2009), Biblical Interpritation among the Anabaptist Reformers in Hauser A. J., Watson D. F., A History of Biblical Interpretation, 2, The Medieval through the Reformation Periods, Grand Rapids, MI, Eerdmans.

31. Packer, J. I. (1973), "Sola Scriptura" in History and Today in John W. Montgomery (ed.), God's Inerrant Word: An International Symposium on the Trustworthiness of Scripture, Minneapolis: Bethany Fellowship, Inc., available at: http://www.ccel.us/ godsinerrantword.ch2.html.

32. Pannenberg, W. (1963), The Crisis of the Scripture-Principle in Protestant Theology, Dialog, 2.

33. Prof. Engelder (1916), The Three Principles of the Reformation in Prof. W. H. T. Dau (ed.), Four Hundred Years : Commemorative Essays on the Reformation of Dr. Martin Luther and Its Blessed Results, Concordia Publishing House.

34. Thorsen, D., Solus Gratia, Solus Fide, and Solus Scriptura: Reforming Protestant Principles to Serve the Present Age, Oxford Institute of Methodist Theological Studies, available at: https://oimts.files.wordpress.com/2013/04/2007-4-thorsen.pdf.

35. Wells, D. F. (1993), No Place for Truth: or Whatever Happened to Evangelical Theology?, Wm. B. Eerdmans Publishing.

36. Williams, G. H. (1995), The Radical Reformation (3rd Ed.: Sixteenth Century Essays \& Studies), Truman State University Press.

(C) Санніков Сергій

Надійшла до редакції 21.06.2017 